\title{
OMITTING THE STATIC COMPONENT FROM DESIGN DYNAMIC MODELS OF PEDESTRIAN LOAD
}

\author{
Ivana Štimac Grandić \\ University of Rijeka, Faculty of Civil Engineering, Assistant Professor \\ Corresponding author: istimac@gradri.uniri.hr \\ Dario Jakovljević \\ Nedešćina Graditeljstvo d.o.o, mag.ing.aedif. \\ Davor Grandić \\ University of Rijeka, Faculty of Civil Engineering, Assistant Professor
}

\begin{abstract}
In current codes and guidelines for pedestrian bridge design, the vibration serviceability requirement is determined as a pedestrian comfort criteria, by assessing the maximum acceptable acceleration of any part of the bridge deck, but these criteria can also be defined as the maximum acceptable deflection or velocity at the most unfavorable part of the bridge deck. The design models of dynamic pedestrian load for serviceability limit state (SLS) verification are based on experimental models of dynamic pedestrian load; however, design models of vertical pedestrian load omit the static component of pedestrian weight. In this study, we compare the dynamic responses of different single-span bridge decks, each with a resonance frequency of $2 \mathrm{~Hz}$. We show that omitting the static component is appropriate when defining the comfort criteria by using the maximum acceptable bridge deck velocity or acceleration.
\end{abstract}

Keywords: dynamic pedestrian load model, pedestrian bridges, SLS

\section{UTJECAJ IZOSTAVLJANJA STATIČKE KOMPONENTE IZ PRORAČUNSKIH MODELA DINAMIČKOG PJEŠAČKOG OPTEREĆENJA MOSTOVA}

Sažetak: Kriterij udobnosti u suvremenim normama i smjernicama za projektiranje pješačkih mostova se definira prihvatljivim vrijednostima najvećih ubrzanja rasponskog sklopa mosta, premda se kriteriji mogu definirati i prihvatljivom veličinom progiba ili brzine bilo kojeg djela rasponskog sklopa mosta. U proračunskim modelima dinamičkog pješačkog opterećenja za dokaz graničnog stanja uporabljivosti (GSU), koji su bazirani na eksperimentalnim modelima dinamičkog pješačkog opterećenja u vertikalnom smjeru, izostavljena je statička komponenta (težina pješaka). Iz provedenih proračuna na nekoliko jednorasponskih konstrukcija s vlastitom frekvencijom $2 \mathrm{~Hz}$ i usporedbe dinamičkih odgovora (pomaka, brzine i ubrzanja) rasponske konstrukcije vidljivo je da je isključenje statičke komponente opravdano u slučajevima kad su kriteriji udobnosti definirani kao najveće prihvatljive brzine ili ubrzanja rasponskog sklopa konstrukcije

Ključne riječi: modeli dinamičkog pješačkog opterećenja, pješački most, GSU 


\section{INTRODUCTION}

Verifying the serviceability limit state (SLS) of footbridges includes checking the limit state for vibration caused by pedestrian traffic because, when pedestrians move over a bridge, walking with a step frequency identical to a natural frequency of the bridge can cause resonance [1]. When walking, pedestrians have step frequencies identical to the vertical frequencies of the first harmonic, generally $1.6-2.4 \mathrm{~Hz}$, while when running they are 2.5$3.5 \mathrm{~Hz}[2,3]$. Bridges can be excited not only by the first harmonic but also by the second harmonic. For walking, the vertical frequency of the second harmonic is twice that of the step frequency, 3.2-4.8 Hz [3]. Because of these frequencies, most current codes and design guides, as well as some older codes [4-9], give limit values for SLS verification related to pedestrian vibrations with frequencies less than $5 \mathrm{~Hz}$; the only exception is the SETRA technical guide [10], which gives a limit value of $4.5 \mathrm{~Hz}$.

The SLS of footbridges for pedestrian vibration is verified by comparing the bridge's structural response under dynamic pedestrian loading with the comfort criteria given in codes or design guides. Most contemporary codes and guidelines define the comfort criteria as a maximum acceleration at any part of the bridge deck [3-5, $8-10]$, although it may be defined as a maximum deflection [3,11-13] or velocity $[2,11,13]$. Table 1 and Figure 1 show some examples of limit values for acceleration and deflection.

Table 1 Limit values for vertical acceleration $\left[\mathrm{m} / \mathrm{s}^{2}\right]$

\begin{tabular}{|l|l|}
\hline HRN EN 1990 [4], ENV 1995-2 [9] & 0.7 \\
\hline HRN ENV 1992-2 [8], BS 5400 [6], & $0.5 \cdot f_{v}^{1 / 2}$ \\
\hline Hong Kong Structures Design [3] & $0.25 \cdot f_{v} .78$ \\
\hline Ontario Bridge Code ONT 83 [3] & 1.0 \\
\hline Japanese Footbridge Design Code [3] & $<0.5$ for maximum comfort \\
\hline SETRA [10] & $0.5-1.0$ for average comfort \\
& $>1.0-2.5$ for minimum comfort \\
& (the owner defines the comfort level) \\
\hline NA to BS EN 1991-2 [15] & $0.5-2.0$ (depending on site usage, route redundancy, \\
& structure height, and exposure) \\
\hline
\end{tabular}

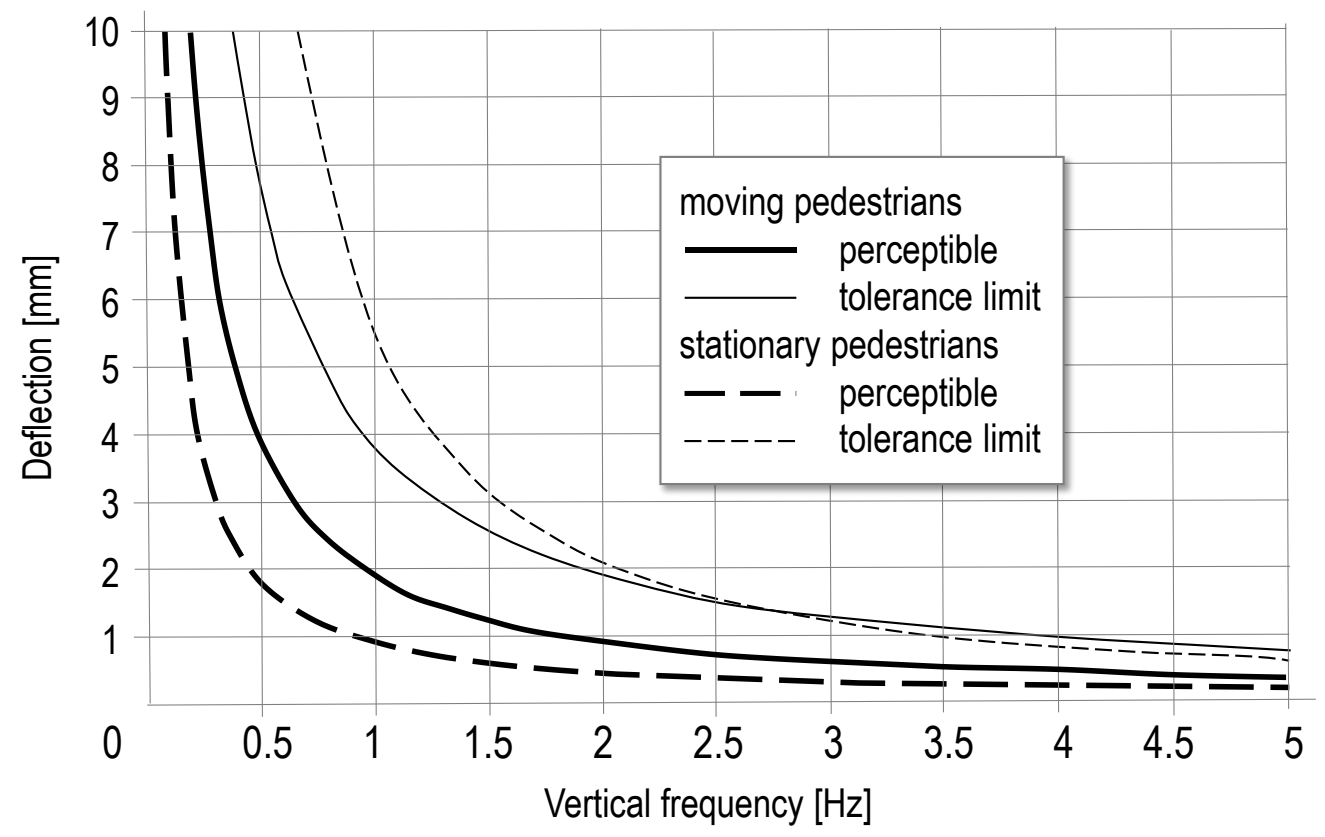

Figure 1 Perception and tolerance limits for vertical vibrations according to [12] 
To conduct dynamic analysis and calculate the dynamic response for the acceleration, velocity, or displacement of the bridge superstructure, one must know the dynamic excitation caused by pedestrian; in other words, the dynamic model of pedestrian loads.

In Croatia, the current code for defining traffic loads on bridges [1] as well as its Croatian National Annex [14] does not define dynamic models of pedestrian loads for dynamic analysis and verification of the SLS for vibrations; however, these models are defined in other codes, design guides, and National Annexes to Eurocode in other countries $[8-10,13,15,16]$.

All design load models are based on experimental load models, which are derived from measuring the walking force of a single pedestrian on a rigid surface. Unlike in experimental load models, which use both static and dynamic vertical force components, design load models omit the static component (pedestrian weight) [3].

In this study, we aim to justify omitting the static component of vertical force from dynamic design load models for pedestrians walking on a footbridge.

\section{EXPERIMENTAL AND DESIGN DYNAMIC MODELS OF PEDESTRIAN VERTICAL-LOAD COMPONENT}

\subsection{Experimental load models (ELMs)}

Experimental dynamic models of the pedestrian vertical-load component assume that the force of pedestrian walking can be considered a periodic function in time [3] and can be described by a Fourier series as follows:

$$
F(t)=G+G \sum_{i=1}^{n} \alpha_{i} \sin \left(2 \cdot \pi \cdot i \cdot f_{s} \cdot t-\varphi_{i}\right)
$$

where $F(t)$ is the total walking force in time, $G$ is thestatic component (pedestrian weight), $f_{s}$ is the step frequency, $\alpha_{i}$ is the Fourier coefficient of the ith harmonic, $n$ is the total number of participating harmonics, and $\varphi$ is the phase angle of the ith harmonic. In previous works, the total number of participating harmonics, and thus the number of corresponding Fourier coefficients, varies from 1 to $5[2,3,7,13,17]$.

Though the predicted and measured vertical components of walking force are similar only when accounting for three or more harmonics, one can ignore the contribution of the second and higher harmonics when determining the most unfavorable dynamic response of the structure [18].

For example, in 1977 Blanchard et al. proposed the first dynamic model of vertical pedestrian force, which has only one harmonic besides the static component; in other words, it has only one Fourier coefficient, $\alpha_{1}=0.257$. They obtained $\alpha_{1}$ by summing successive impulses from the left and right foot at $1.8 \mathrm{~Hz}$, measured on a gait machine [7]. However, later research concluded that the Fourier coefficient found by Blanchard et al. has great shortcomings [3].

Walking forces with one harmonic have been defined by Charles and Hooprah as $\alpha_{1}=0.4$ [19] and by Fanning as $\alpha_{1}=0.25 \cdot f_{s}-0.1[18]$.

Bachmann and Amman were the first to define more than one harmonic (linear interpolation for $\alpha_{1}$ between 0.4 and 0.5 for frequencies of $2-2.4 \mathrm{~Hz}, \alpha_{2}=\alpha_{3}=0.1$ ) [17].

A review paper by Živanović et al. [3] noted that Peterson and Kerr defined three harmonics, Young and Rainer defined four harmonics, and Schulze defined five harmonics [20]. Petersen and Kerr, Young and Rainer, and Schulze defined Fourier coefficient for the first harmonic that depend on the step frequency, but they defined those of higher harmonics as constant and independent of step frequency. Most experimental dynamic models of the vertical component of walking force do not define a phase angle; that is, it can be considered equal to zero $[13,19]$. Bachmann and Amman defined the phase angle for the second and third harmonics as $\varphi_{2}=\varphi_{3}=\pi / 2$ [17], while Petersen suggested $\varphi_{2}=\varphi_{3}=\pi / 5$ for step frequencies of $1.5 \mathrm{~Hz}$ and $2 \mathrm{~Hz}$ and suggested $\varphi_{2}=\varphi_{3}=2 \pi / 5$ at a step frequency of $2.5 \mathrm{~Hz}[20]$. 


\subsection{Design load models (DLMs)}

The design dynamic model of vertical walking force for a single pedestrian is commonly defined as a periodic pulsating force:

$$
F(t)=G_{1} \cdot \sin \left(2 \cdot \pi \cdot f_{v} \cdot t\right)
$$

where $G_{1}=G \cdot \alpha_{1}$ andf $f_{v}$ is the fundamental bridge frequency in the vertical direction. The pulsating force is not stationary; rather, it moves with a constant speed along the bridge $[6,8,9,13,15,19]$.

The first design load model for checking pedestrian vibrations on footbridges was incorporated in the British Standard dealing with the design of steel, concrete, and composite bridges from 1978 [6]. This model was based on the research of Blanchard et al. from 1977. Its mathematical description is identical to Equation (2), and the amplitude of pulsating force $G_{1}$ is defined as $180 \mathrm{~N}\left(\alpha_{1}=0.257, G=700 \mathrm{~N}\right)$. This design model has been adopted in some national codes, such as the Ontario Bridge Design Code, the Canadian Highway Bridge Design Code, and the Hong Kong Structures Design Manual for Highways and Railways [3], as well as in the European prenorm for concrete bridges ENV 1992-2 [9]. Other codes and guides, including newer versions of the design models, retain the mathematical formulation in Equation (2) but define $G_{1}$ as $280 \mathrm{~N}\left(\alpha_{1}=0.4, G=700 \mathrm{~N}\right)[8,10,13,16,19]$.

As mentioned before, design load modelsomit the static component and higher harmonics, and the excitation frequency (step frequency) is identical to the fundamental vertical frequency of the bridge deck, $f_{s}=f_{v}$. The Fourier coefficient for the first harmonic $\alpha_{1}$ is constant and independent of excitation frequency.

\section{CALCULATION OF STRUCTURAL DYNAMIC RESPONSE CAUSED BY DLM AND ELM}

We conducted dynamic analysis on various single-span bridge decks: simple supported beam bridge decks (simple supported decks) with spans of $15 \mathrm{~m}, 30 \mathrm{~m}$, and $45 \mathrm{~m}$, and a beam bridge deck fixed at both supports (fixed deck) with a span of $30 \mathrm{~m}$. These decks have a fundamental natural frequency of $2 \mathrm{~Hz}$, identical to the mean walking frequency [3]. We performed dynamic analysis using the DARK software package, suitable for dynamic analysis of 2D structures under moving constant or pulsating forces [21, 22]. From this analysis, we calculated the deflections, velocities, and accelerations of the deck structures under experimental and design load models.

\subsection{Data required for analysis}

This chapter presents the basic data needed to conduct dynamic analysis of the bridge deck under ELMs and DLMs using DARK. For this analysis, the ELM and DLM must be specified.

The ELM of the vertical component of walking is the sum of the static component (pedestrian weight) and dynamic component, which includes only the first harmonic. In contrast, the DLM is only the dynamic component (first harmonic).

In most current codes and design guides, the base for modeling different vertical pedestrian loads (individuals, groups, or continuous flow) is the force of a single pedestrian with the amplitude of the dynamic pulsating component $G_{1}=280 \mathrm{~N}\left(G=700 \mathrm{~N}, \alpha_{1}=0.4\right)[9,10,13,15,16,19]$. The coefficient $\alpha_{1}=0.4$ correlates with the Fourier coefficient for the first harmonic given in ELMs by Charles and Hooprah [21], Bachmann and Ammann [17], Fanning [18], and Petersen [20], based on measuring the force at a step frequency of $2 \mathrm{~Hz}$.

The ELM we used for dynamic analysis is:

$$
F^{E L M}(t)=700+280 \cdot \sin \left(2 \cdot \pi \cdot f_{s} \cdot t\right)
$$

while the design load model is:

$$
F^{D L M}(t)=280 \cdot \sin \left(2 \cdot \pi \cdot f_{v} \cdot t\right)
$$


The pulsating part of the excitation force causes the worst dynamic impact if the excitation frequency equals the natural frequency of the structure. Therefore, the step frequency in Equation (2) is set equal to the deck frequency: $f_{s}=f_{v}=2 \mathrm{~Hz}$. The speed of the excitation force (walking speed) along the bridge is $v_{F}=0.9 \cdot f_{v}=0.9 \cdot f_{s}=1.8$ $\mathrm{m} / \mathrm{s}[6,8,9,13]$. The total time $T$ of the force acting equals the time needed for the pedestrian to cross the span $L: T=L / V_{F}$.

The deck structure with a span length $L$ is modeled using $n$ beam finite elements. Each finite element is defined by the following geometrical, material, and cross-sectional properties: element length $\Delta L=L / n$, dynamic modulus of elasticity $E_{d}$, moment of inertia $I$, specific weight $\gamma$, and cross-sectional area $A$. We also specify the structural damping $\zeta$, number of time steps $m$, duration of each time step $\Delta t$, force speed $v_{F}$, amplitude of pulsating force component $G_{1}$, and static force component $G$ (for analysis of experimental load model). The relationship between the number of time steps and the duration of a time step is $T=m \cdot \Delta t$.

\subsection{Dynamic analysis of simple supported deck with length of 15 meters}

The finite element properties and parameters required to conduct dynamic analysis under the ELM and DLM, listed in chapter 3.1, are: $n=50, \Delta L=0.3 \mathrm{~m}, E_{d}=3.36 \cdot 10^{7} \mathrm{kN} / \mathrm{m}^{2}, I=6.8 \cdot 10^{-3} \mathrm{~m}^{4}, \gamma=25 \mathrm{kN} / \mathrm{m}^{3}, A=1.202 \mathrm{~m}^{2}, \zeta=1.3 \%$, $m=1000, \Delta t=0.00833 \mathrm{~s}, v_{F}=1.8 \mathrm{~m} / \mathrm{s}, G_{1}=280 \mathrm{~N}, G=700 \mathrm{~N}$.

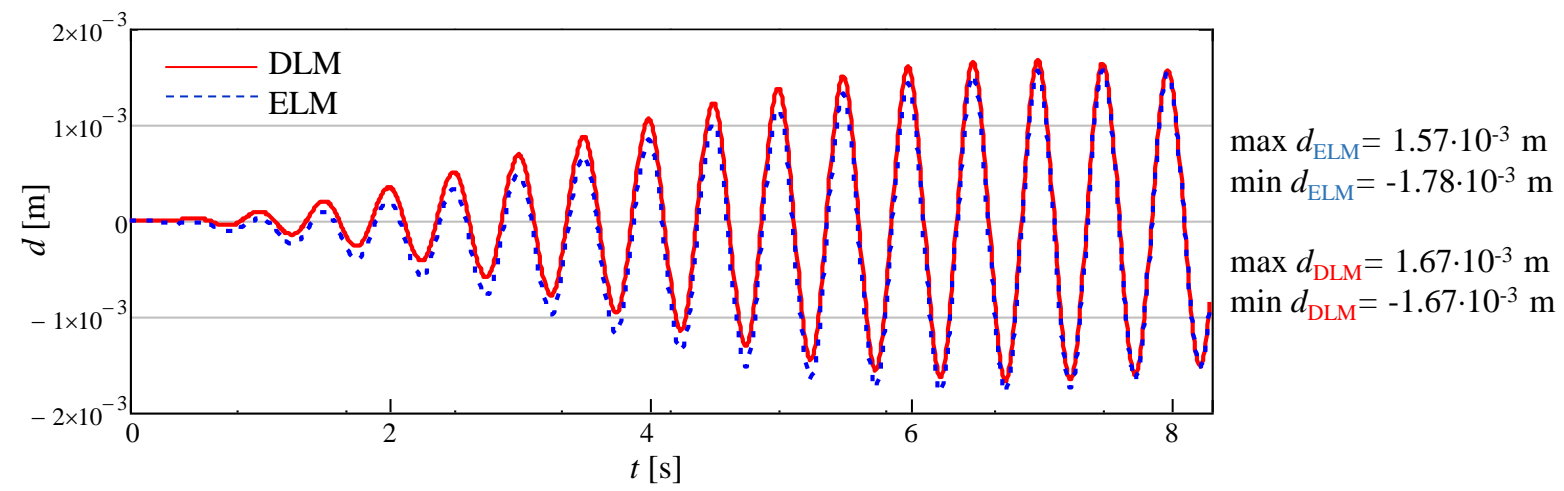

Figure 2 Time history of displacement in the middle of the simple supported deck, L=15 $\mathrm{m}$

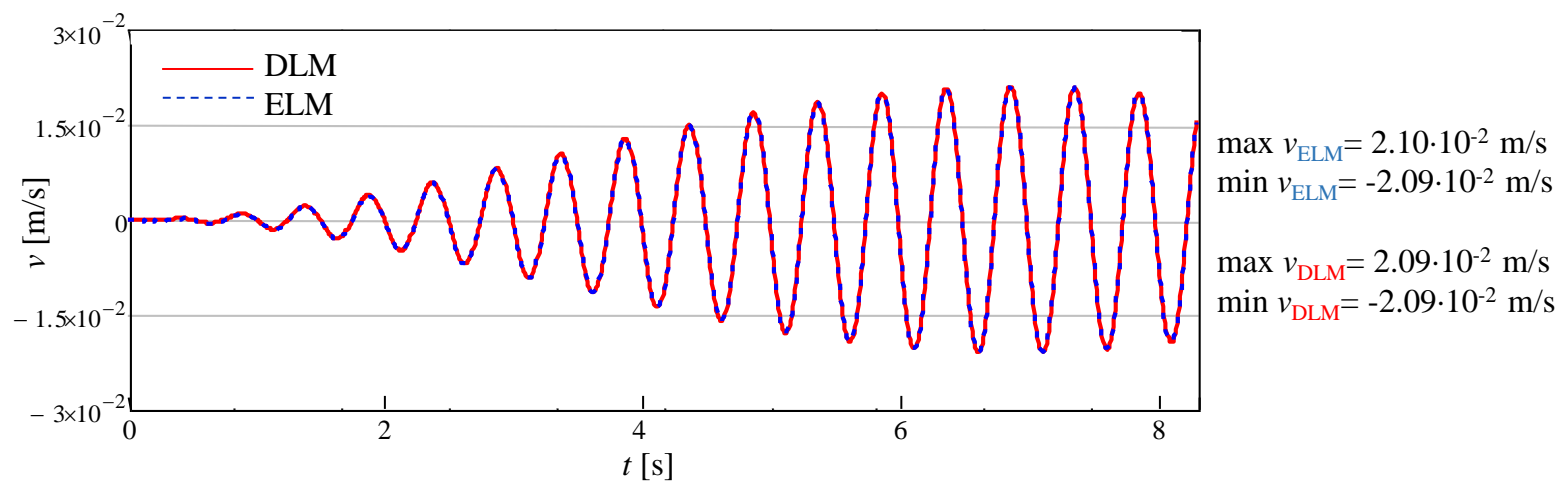

Figure 3 Time history of velocity in the middle of the simple supported deck, L=15 m 


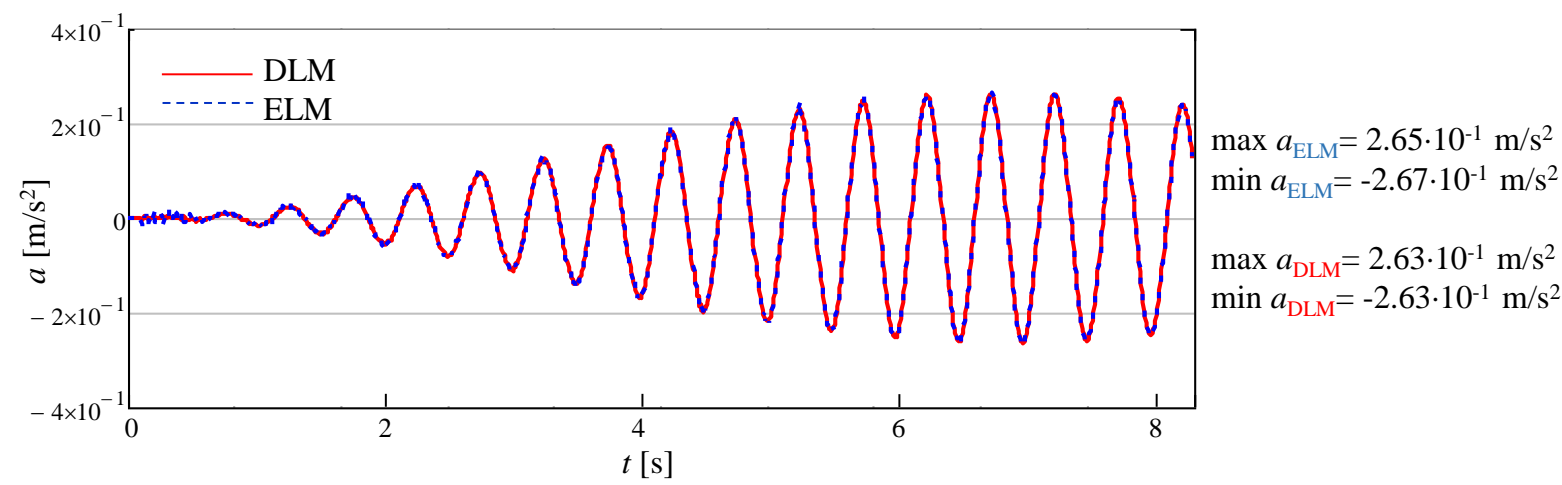

Figure 4 Time history of acceleration in the middle of the simple supported deck, L=15 m

Figures 2-4 show the displacement, velocity, and acceleration over time at the most unfavorable position of the deck, in the middle of the span, for a simple supported bridge deck with a length of $15 \mathrm{~m}$ exposed to the DLM and ELM.

\subsection{Dynamic analysis of simple supported deck with length of 30 meters}

The finite element properties and parameters required to conduct dynamic analysis under the ELM and DLM, listed in chapter 3.1, are: $n=100, \Delta L=0.3 \mathrm{~m}, E_{d}=3.36 \cdot 10^{7} \mathrm{kN} / \mathrm{m}^{2}, \quad l=4.35 \cdot 10^{-1} \mathrm{~m}^{4}, \gamma=25 \mathrm{kN} / \mathrm{m}^{3}, A=4.372 \mathrm{~m}^{2}$, $\zeta=1.3 \%, m=1000, \Delta t=0.01666 \mathrm{~s}, v_{F}=1.8 \mathrm{~m} / \mathrm{s}, G_{1}=280 \mathrm{~N}, \mathrm{G}=700 \mathrm{~N}$.

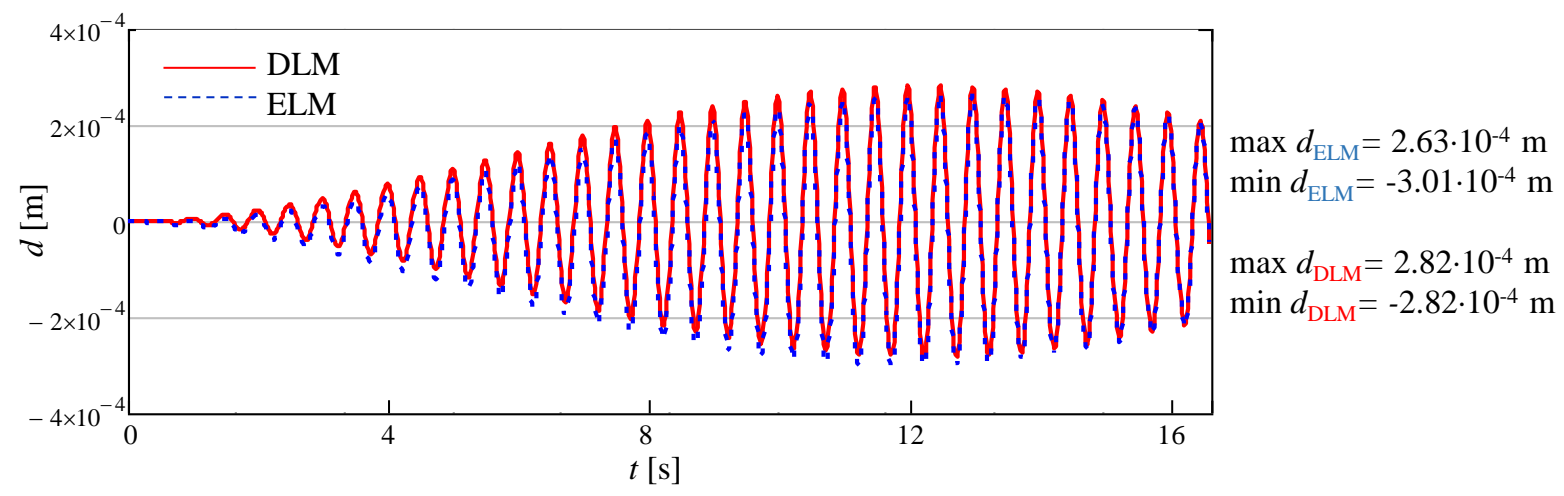

Figure 5 Time history of displacement in the middle of the simple supported deck, L=30 m

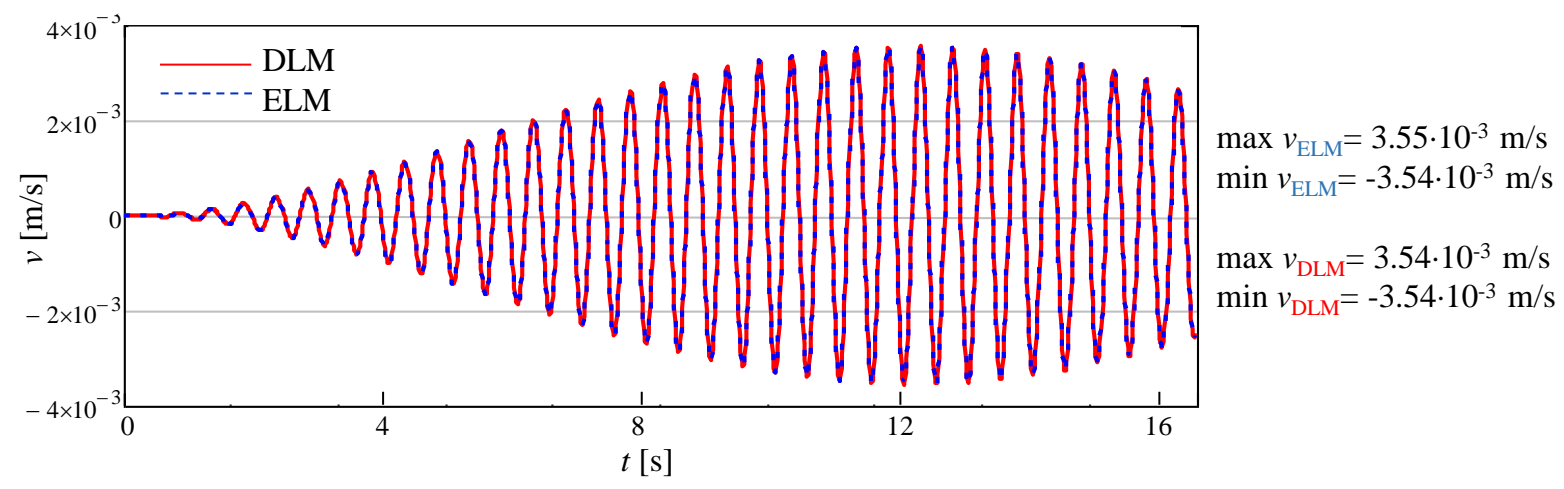

Figure 6 Time history of velocity in the middle of the simple supported deck, L=30 m 


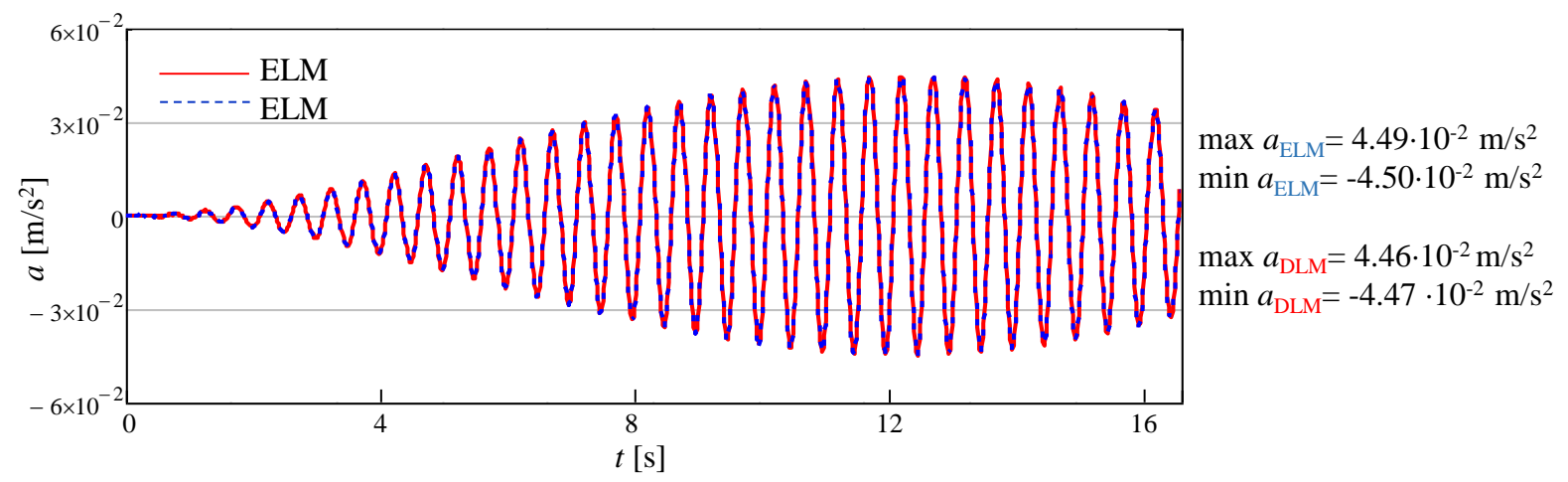

Figure 7 Time history of acceleration in the middle of the simple supported deck, L=30 m

Figures 5-7 show the displacement, velocity, and acceleration over time at the most unfavorable position of the deck, in the middle of the span, for a simple supported bridge deck with a length of $30 \mathrm{~m}$ exposed to the DLM and ELM.

\subsection{Dynamic analysis of simple supported deck with length of 45 meters}

The finite element properties and parameters required to conduct dynamic analysis under the ELM and DLM, listed in chapter 3.1, are: $n=150, \Delta L=0.3 \mathrm{~m}, E_{d}=3.36 \cdot 10^{7} \mathrm{kN} / \mathrm{m}^{2}, l=4.957 \mathrm{~m}^{4}, \gamma=25 \mathrm{kN} / \mathrm{m}^{3}, A=9.836 \mathrm{~m}^{2}, \zeta=1.3 \%$, $m=1000, \Delta t=0.025 \mathrm{~s}, v_{F}=1.8 \mathrm{~m} / \mathrm{s}, G_{1}=280 \mathrm{~N}, \mathrm{G}=700 \mathrm{~N}$.

Figures 8-10 show the displacement, velocity, and acceleration over time at the most unfavorable position of the deck, in the middle of the span, for a simple supported bridge deck with a length of $45 \mathrm{~m}$ exposed to the DLM and ELM.

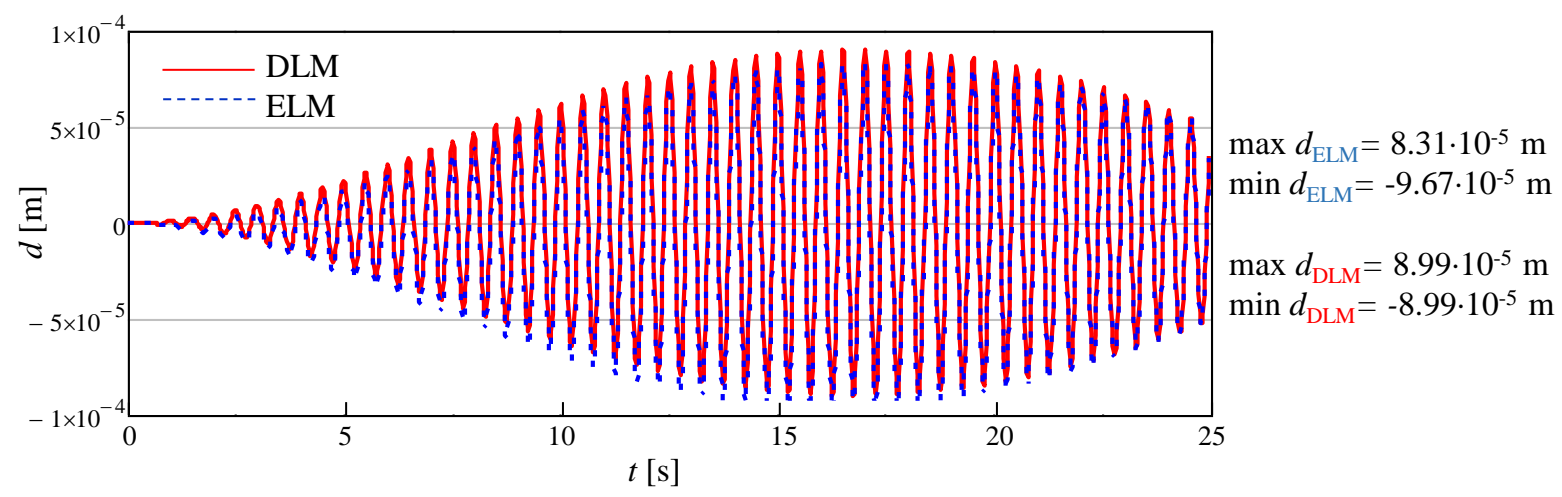

Figure 8 Time history of displacement in the middle of the simple supported deck, L=45 m

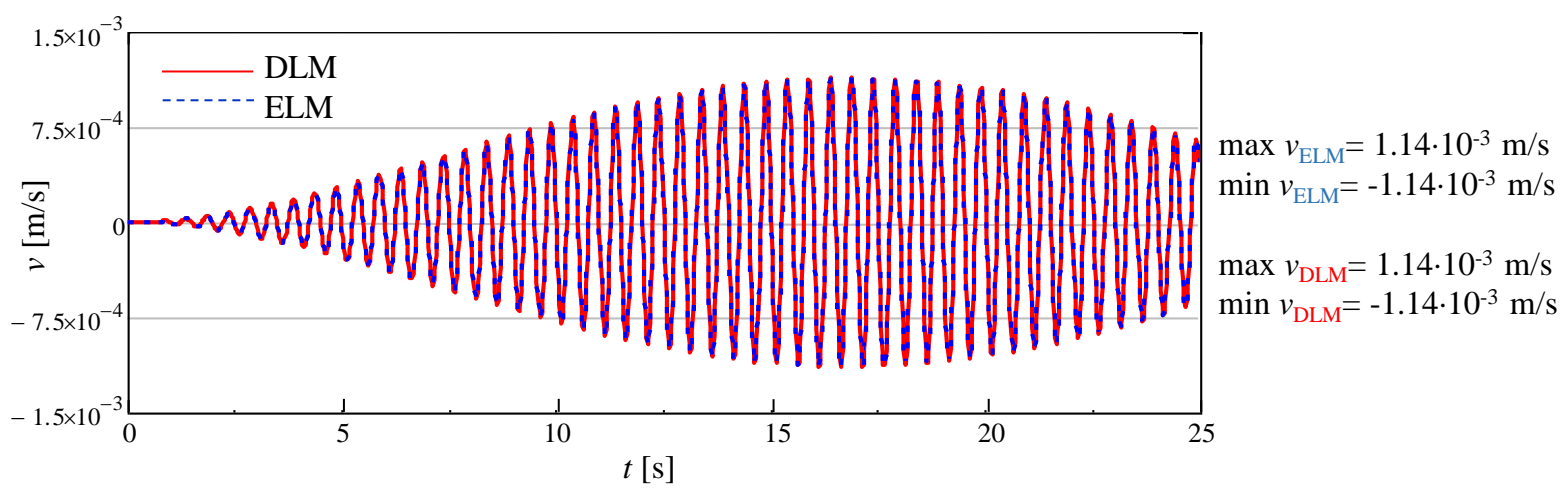

Figure 9 Time history of velocity in the middle of the simple supported deck, $L=45 \mathrm{~m}$ 


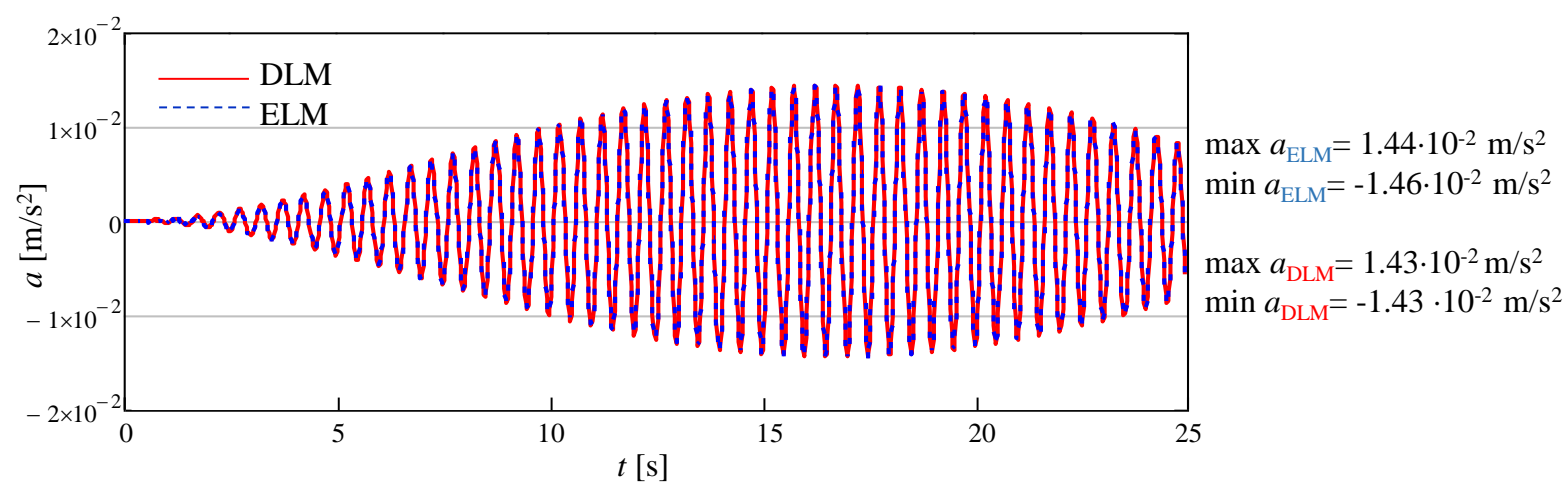

Figure 10 Time history of acceleration in the middle of the simple supported deck, $L=45 \mathrm{~m}$

\subsection{Dynamic analysis of fixed deck with length of 30 meters}

The finite element properties and parameters required to conduct dynamic analysis under the ELM and DLM, listed in chapter 3.1, are: $n=100, \Delta L=0.3 \mathrm{~m}, E_{d}=3.36 \cdot 10^{7} \mathrm{kN} / \mathrm{m}^{2}, l=3.8 \cdot 10^{-2} \mathrm{~m}^{4}, \gamma=25 \mathrm{kN} / \mathrm{m}^{3}, A=1.95 \mathrm{~m}^{2}, \zeta=1.3 \%$, $m=1000, \Delta t=0.01333 \mathrm{~s}, v_{F}=1.8 \mathrm{~m} / \mathrm{s}, G_{1}=280 \mathrm{~N}, G=700 \mathrm{~N}$. Figures $11-13$ show the displacement, velocity, and acceleration over time for a fixed bridge deck with a length of $30 \mathrm{~m}$ in the most unfavorable position exposed to the DLM and ELM.

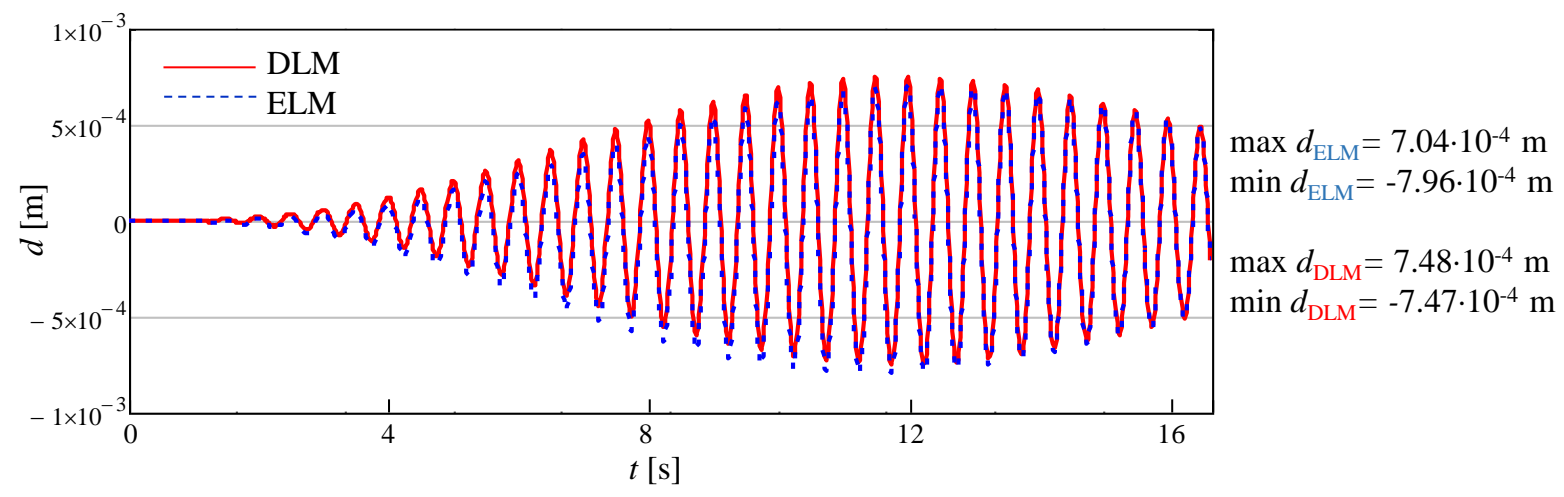

Figure 11 Time history of displacement in the middle of the fixed deck, $\mathrm{L}=30 \mathrm{~m}$

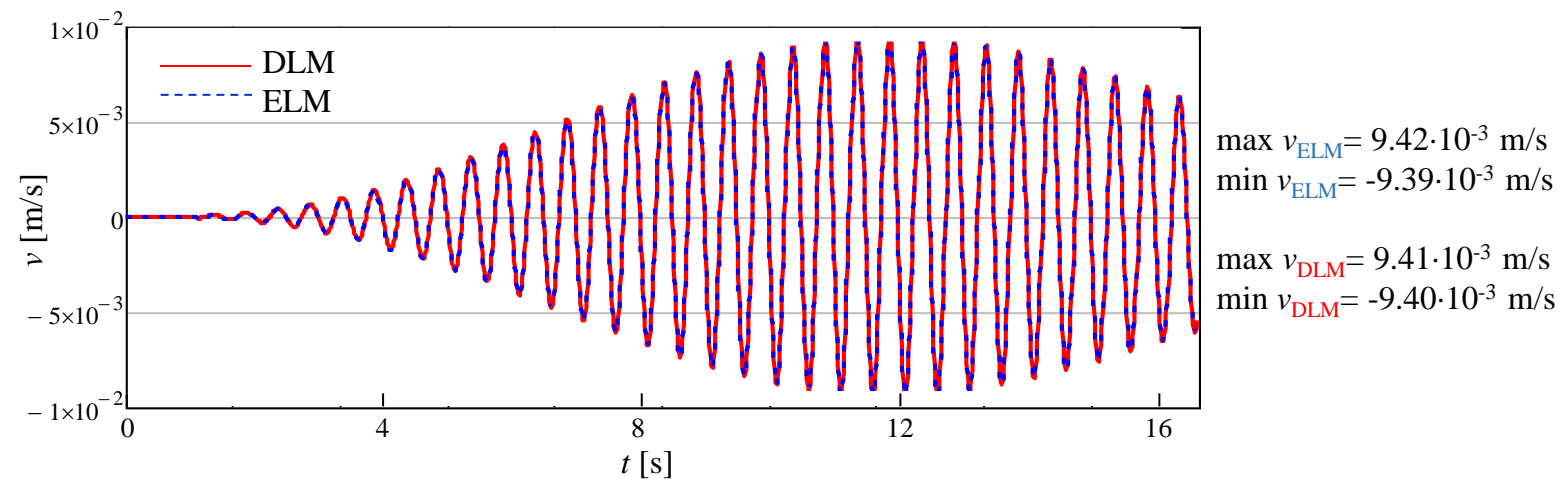

Figure 12 Time history of velocity in the middle of the fixed deck, L=30 m 


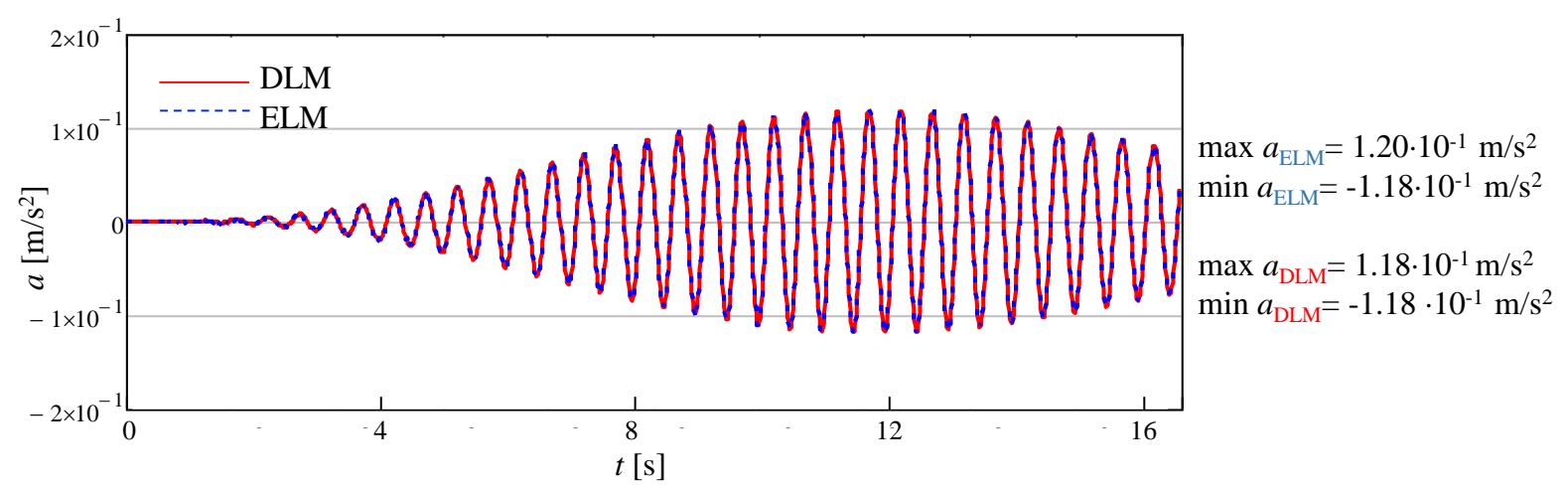

Figure 13 Time history of acceleration in the middle of the fixed deck, $L=30 \mathrm{~m}$

\section{DISCUSSION AND CONCLUSION}

Considering the dynamic analysis in chapter 3 and results in Figures 2-13, we find significant differences in the structural dynamic response in dynamic displacement under the ELM and DLM.

As shown in Figures 2, 5, 8, and 11, the maximum deflections (max) under the ELM are smaller than those under the DLM; the minimum deflections (min) under the ELM are also smaller than those under the DLM. The deviations in minimums and maximums of displacement under the ELM and DLM vary from $6 \%$ to $9.6 \%$, as shown in Table 2.

Table 2 Deflection deviation and deflection difference for the DLM and ELM

\begin{tabular}{|l|l|l|l|}
\hline $\begin{array}{l}\text { Bridge deck structural } \\
\text { system }\end{array}$ & $\begin{array}{l}\text { Span length } \\
{[\mathrm{m}]}\end{array}$ & $\begin{array}{l}\text { Deflection deviation [\%] } \\
\left(\frac{\left|v_{E L M}-v_{D L M}\right|}{v_{D L M}}\right) \cdot 100 \%\end{array}$ & $\begin{array}{l}\text { Deflection difference [m] } \\
\left|v_{E L M}-v_{D L M}\right|\end{array}$ \\
\hline Simple supported beam & 15 & $\begin{array}{l}6.0 \%(\max ) \\
6.6 \%(\min )\end{array}$ & $0.1 \cdot 10^{-3}(\max )$ \\
& 30 & $6.7 \%(\max )$ & $0.11 \cdot 10^{-3}(\min )$ \\
\cline { 2 - 4 } & & $6.7 \%(\min )$ & $0.19 \cdot 10^{-4}(\max )$ \\
& 45 & $9.45 \%(\max )$ & $0.19 \cdot 10^{-4}(\min )$ \\
\hline Fixed beam & $30.6 \%(\min )$ & $0.68 \cdot 10^{-5}(\max )$ \\
& 30 & $5.9 \%(\max )$ & $0.44 \cdot 10^{-4}(\max )$ \\
\hline
\end{tabular}

The absolute values of the deflection differences shown in Table 2 correspond to the values of static deflection in the middle of the span caused by a force of $700 \mathrm{~N}$ acting at the position of greatest calculated dynamic deflection (Figure 14); that is, the difference in deflections is caused by omitting the static component from the DLM. 

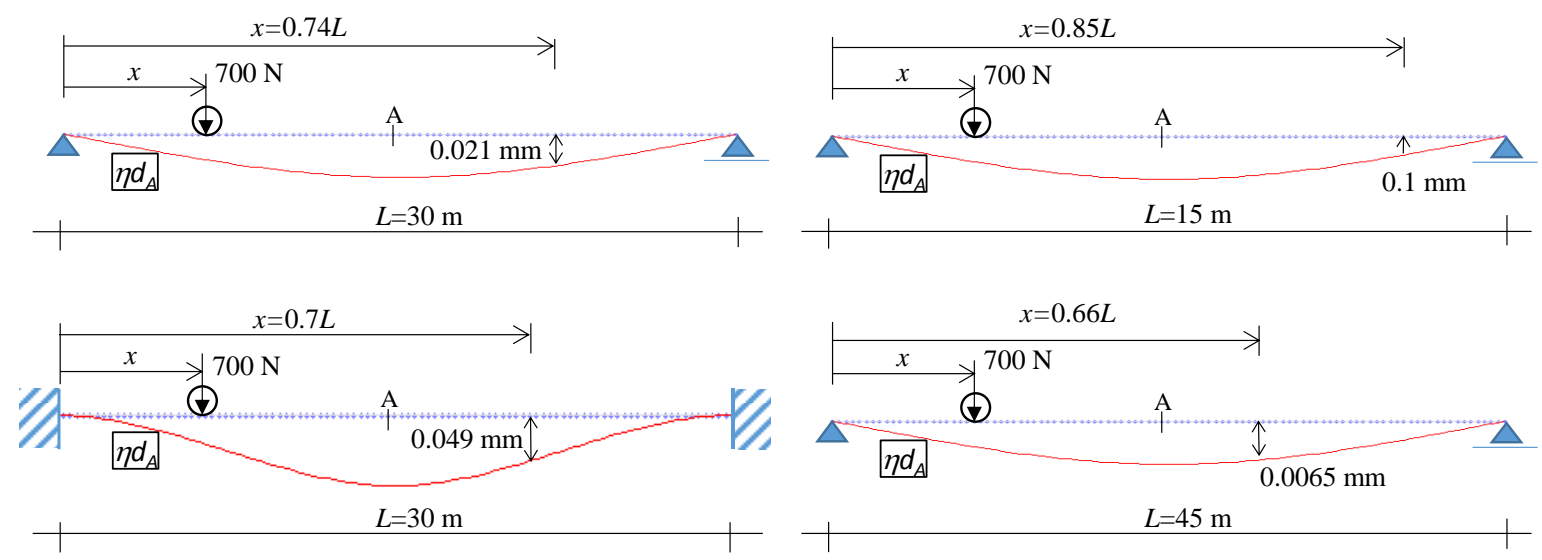

Figure 14 Influence lines of middle-span deflection caused by a force of $700 \mathrm{~N}$

The velocities and accelerations, calculated at the most unfavorable part of the deck structure, do not deviate significantly between the DLM and ELM, whether visually or numerically.

From these analyses and comparisons of calculated displacements, velocities, and accelerations, we conclude that, when verifying the serviceability limit state for pedestrian-induced vertical vibration, omitting the static component from the DLM is reasonable when the comfort criteria is defined as the greatest acceptable acceleration or velocityof the bridge deck, as is common in most design codes and design guides.

\section{Acknowledgment}

This paper is a part of research supported by University of Rijeka through Grant No. 13.05.1.1.01. The authors are grateful for this support.

\section{References}

[1] HRN EN 1991-2:2012 Eurokod 1: Djelovanja na konstrukcije - 2. dio: Prometna opterećenja mostova, Hrvatski zavod za norme, Zagreb, 2012.

[2] Stráský, J. 2005: Stress Ribbon and Cable-Supported Pedestrian Bridges. Thomas Telford, London.

[3] Živanović, S.; Pavic, A.; Reynolds, P. 2005: Vibration serviceability of footbridges under human-induced excitation: a literature review, Journal of Sound and Vibration, Volume 279, pp. 1-74.

[4] HRN EN 1990:2011, Eurokod: osnove projektiranja konstrukcija. Hrvatski zavod za norme, Zagreb, 2011.

[5] Guide Specifications for Design of FRP Pedestrian Bridges. American Association of State Highway and Transportation Officials (AASHTO), 2008.

[6] Steel, Concrete and Composite Bridges - Part 2: Specification for Loads; Appendix C: Vibration Serviceability Requirements for Foot and Cycle Track Bridges, BS 5400. UK: British Standards Association, London, 1978.

[7] Blanchard, J.; Davies, L. B.; Smith, J. W.: 1977: Design criteria and Analysis for Dynamic Loading of Footbridges, Symposium on Dynamic Behaviour of bridges, Crowthorne, Berkshire.

[8] HRN ENV 1992-2:1996, Eurokod 2: Projektiranje betonskih konstrukcija - 2. dio: Betonski mostovi. Državni zavod za normizaciju i mjeriteljstvo, Zagreb, 2004.

[9] ENV 1995-2: 1997, Eurocode 5: Design of Timber Structures - Part 2: Bridges. European Committee for Standardization, Brussels, 1997.

[10] Footbridges: Assessment of vibrational behaviour of footbridges under pedestrian loading- Technical guide. SETRA, Association Francaise de Dgenie Civil, 2006.

[11] Murray, T. M.; Allen, D. E.: Ungar, E. E. 1997: Floor Vibrations Due to Human Activity, American Institute of Steel Construction, Inc., USA.

[12] Hirt, M.; Lebet, J.-P. 2013: Steel bridges: Conceptual and Structural Design of Steel and Steel-Concrete Composite Bridges, EFPL Press, Lausanne, 2013. 
[13] FIB Bulletin 32: Guidelines for the design of footbridges. CEB, Stuttgart, 2005.

[14] HRN EN 1991-2:2012/NA, Eurokod 1: Djelovanja na konstrukcije - 2. dio: Prometnao pterećenja mostova Nacionalni dodatak, Hrvatski zavod za norme, Zagreb, 2012.

[15] NA to BS EN 1991-2:2003, UK National Annex to Eurocode 1: Actions on structures - Part 2: Traffic loads on bridges, BSI, 2008.

[16] Sanpaolesi, L.; Croce, P., eds. 2004: Guide to basis of bridge design related to Eurocodes supplemented by practical design - Handbook 4. Leonardo da Vinci pilot project, Pisa.

[17] Bachmann, H. et al. 1995: Vibration problems in structures: practical guidelines. Birkhauser Verlag Basel, Basel.

[18] Fanning, J. P.; Archbold, P.; Pavic, A. 2005: Proceeding of 2005 Society for Experimental mechanics Annual Conference on Experimental and Applied Mechanics, Portland, Oregon, June 7-9, 2005.

[19] Heinemeyer, C. et al. 2009: Design of Lightweight Footbridges for Human Induced Vibrations - Background document in support to the implementation harmonization and further development of the Eurocodes, European Commission, Institute for the Protection and Security of the Citizen, Italy.

[20] Blanco, C. M. et al. 2005: Structural Dynamic design of a footbridge under pedestrian loading, Proceeding of 9th SAMTECH Users Conference, Paris, pp. 1-19.

[21] Štimac, I.; Meštrović, D.; Kožar, I. 2004: Analiza mostovnih konstrukcija pobuđenih pokretnim opterećenjem, Građevinar, Vol. 56, br. 6, str. 347-353.

[22] Štimac Grandić, I.; Jug, D.; Grandić, D. 2014: Proračun vertikalnih ubrzanja na pješačkom mostu prema različitim modelima pješačkog dinamičkog opterećenja, 5. Internacionalni naučno-stručni skup građevinarstvo-nauka i praksa - zbornik, Žabljak, str. 855-862 